\title{
Factors influencing performance within startup assistance organizations
}

\author{
Ioana CEAUȘU \\ The Bucharest University of Economic Studies, Bucharest, Romania \\ ioana.ceausu@fabiz.ase.ro \\ Katrin MARQUARDT \\ The Bucharest University of Economic Studies, Bucharest, Romania \\ Sven-Joachim IRMER \\ The Bucharest University of Economic Studies, Bucharest, Romania \\ Elisa GOTESMAN \\ The Bucharest University of Economic Studies, Bucharest, Romania
}

\begin{abstract}
Startup assistance organizations, and especially business accelerators have gained a lot of traction in the last years, captioning not only the attention of the public, but most importantly that of investors and other stakeholders. It has become a challenge for many all around the world to develop such programs, but many have failed or did not have their expected results, meaning medium to longterm sustainable and profitable alumni start-ups. As high amounts of resources, both human and financial, are being invested in the design and development of such programs, it is important to understand what sets apart the successful business acceleration programs from the ones that fail. The current paper is reviewing the up-to-date theoretical literature and studies on the matter at hand, in order to identify the most relevant factors influencing startup assistance organizations' performance. The objective behind identifying these factors is to get a better understanding of best practices of such successful programs and set the basis for future research regarding the development of a set of metrics for more accurately measuring their performance.
\end{abstract}

Keywords: startup assistance organization, business incubator, business accelerator, performance.

\section{Introduction}

Startup assistance organizations (SAOs) have become a point of interest not only for the business environment in the past two decades, but also for the research community, as they focus on offering support to the creation of new ventures - an important driving force of today's global economy. Why some perform and "produce" value adding businesses and some become just co-working spaces are questions risen by both communities (McHugh et al., 2013; Tavoletti, 2013; Theodorakopoulos et al., 2014; 2015 Global Best Practices Report on Incubation and Acceleration by Capria Ventures Ventures LLC; Knott \& Haguewood, 2016).

The aim of this article is to identify the main factors influencing the performance of SAOs in order to get a deeper understanding of best practices and set the basis of future research concerning relevant metrics to evaluate and monitor their performance. 


\section{Defining key concepts}

SAOs include all types of organizations and programs which support entrepreneurs to bring their products or services to the market (Dempwolf et al., 2014). In this paper were taken into consideration business incubators, business accelerators and other non-formal entrepreneurship assistance programs (outside of academic study programs). The selection was made based on the following criteria: (a) duration; (b) access to a network; (c) synergy potential within the program; (d) level of competition among participants/ participant teams within the program. Historically, researchers identify three generations of SAOs with different main goals (Figure 1) (Barrehag et al., 2012).

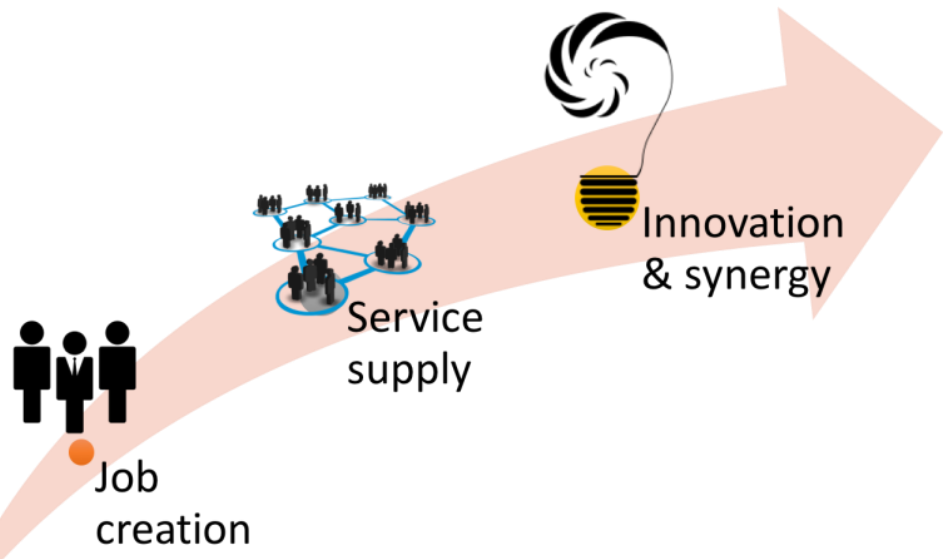

Figure 1. The three generations of SAO goals

Source: Authors' own contribution based on Barrehag et al. (2012).

As their goals evolved, so did their formal organization evolve. The business accelerator (or seed accelerator) derives its characteristics from the business incubator. The term "incubator" was used in the business context in 1959 in New York for the first time when Joseph Mancuso opened the Batavia Industrial Center, as a framework to assist and support new ventures to develop and grow (Barrehag et al, 2012). The concept of business or startup accelerator first came up in 2005 with the launch of Y Combinator in Cambridge, Massachusetts and later moved to Silicon Valley by Paul Graham. For the goal of the present article only these two types of SAO will be taken into consideration. The main differences among these types of SAOs are presented in Table 1 below.

A significant difference among the two is the cost and structure of investments, in a business accelerator these being considerably smaller for each individual new venture (Barrehag et al, 2012). While business incubators usually don't have own funds to invest directly in their participants and, also, do not take equity, business accelerators, usually, invest up to $\$ 25000$ in co-founder teams and take up to $8 \%$ equity in every investee.

Table 1. Business incubators vs. business accelerators

\begin{tabular}{|l|l|l|}
\hline SAO Type & Business Incubators & Business Accelerators \\
\hline Participants & $\bullet \quad \begin{array}{l}\text { All types, including science- } \\
\text { based businesses (such as } \\
\text { biotech, nanotechnology, } \\
\text { clean energy, etc.) }\end{array}$ & $\begin{array}{l}\text { Technology-based ventures (web- } \\
\text { based, apps, cloud-based, software, } \\
\text { etc.) }\end{array}$ \\
& $\begin{array}{l}\text { All ages and genders, } \\
\text { including those with previous }\end{array}$ & $\begin{array}{l}\text { Ventures which do not require } \\
\text { significant immediate investment } \\
\text { or proof of concept }\end{array}$ \\
\hline
\end{tabular}




\begin{tabular}{|c|c|c|}
\hline & $\begin{array}{l}\text { experience in an industry or } \\
\text { sector }\end{array}$ & $\begin{array}{l}\text { Mostly young people, technology } \\
\text { enthusiasts, gamers and hackers } \\
\text { - Focus on small teams, not on } \\
\text { individuals }\end{array}$ \\
\hline Selection process & $\begin{array}{l}\text { - Competitive selection, often } \\
\text { from the local community }\end{array}$ & $\begin{array}{l}\text { Highly competitive open selection, } \\
\text { from wide regions, national or } \\
\text { even global level } \\
\text { - New ventures are assisted in } \\
\text { batches or "classes" }\end{array}$ \\
\hline Duration & $\begin{array}{l}\text { - } 1 \text { to } 5 \text { years (average of } 33 \\
\text { months) }\end{array}$ & - Generally, 3 to 6 months \\
\hline $\begin{array}{l}\text { Type of support } \\
\text { offered }\end{array}$ & $\begin{array}{l}\text { - Access to management and } \\
\text { specialized intellectual } \\
\text { property consulting } \\
\text { - } \quad \text { Access to networks of } \\
\text { experienced entrepreneurs } \\
\text { - } \quad \text { Support entrepreneurs gain } \\
\text { skills } \\
\text { - } \quad \text { Facilitate external financing }\end{array}$ & $\begin{array}{l}\text { - } \quad \text { "Fast-test" validation of ideas } \\
\text { - } \text { functionining prototype and identify } \\
\text { initial customers } \\
\text { - Connecting entrepreneurs to } \\
\text { business consulting and } \\
\text { experienced entrepreneurs } \\
\text { - } \begin{array}{l}\text { Programmed events, intensive } \\
\text { mentoring and business skill }\end{array} \\
\text { workshops } \\
\text { - } \quad \text { Hosting for the web or mobile apps } \\
\text { pssistance in preparing investor } \\
\text { pitches or negotiations }\end{array}$ \\
\hline Investment & $\begin{array}{l}\text { - Usually does not have own } \\
\text { funds to invest directly } \\
\text { More frequently than not, } \\
\text { does not take equity }\end{array}$ & $\begin{array}{l}\text { - Invests } \$ 18000 \text { to } \$ 25000 \text { in teams } \\
\text { of co-founders } \\
\text { Takes equity in every investee } \\
\text { (usually } 4 \text { to } 8 \text { percent) }\end{array}$ \\
\hline
\end{tabular}

Source: Authors' own contribution based on Atkins, 2011 (National Business Incubation Association) \& Miller \& Bound (2011).

\section{Literature review}

The research has taken into consideration articles published in international journals indexed in international article databases and studies conducted by official authorities or private renowned professional organizations (Capria Ventures LLC.; Department of Industry, Innovation \& Economics, Australia; Chalmers University of Technology, Sweden, etc.). The article selection has been made according to following criteria:

- Keywords: startup assistance organizations, business accelerator, business incubator, performance, factors;

- Published date: after 2011 (inclusive).

The results of the literature review synthesis have been grouped into two timeframes, function of publishing date:

- 2011 and 2013;

- 2014 and 2016.

\section{Synthesis of research published between 2011 and 2013}

Research in the time-frame 2011 - 2013 (Table 2) shows that, besides importance of factors such participant selection, support services, duration of the program, network 
opportunities and post-program support (Dalziel, 2012; Chang, 2013; Lall et al., 2013; Tavoletti, 2013), there also other aspects that influence the performance of the SAO.

Ross and Byrd (2011) underline the support services factor by stressing out that these have to enable the innovative concepts and products to reach the market under profitable conditions. Also, they are the first to introduce the importance of focus or at least the need to carefully select the target industries of the ventures a SAO selects in a cohort.

Tseng (2011) takes a human resource development approach to the influence factors and takes into consideration the content of the support services (selection of offered trainings and workshops, the type and quality of assistance offered to participants). His research also brings forward factors such as the ability of the SAO to create opportunities for its participants and to transform property into productivity.

The research conducted by Berrehag et al. (2012) introduces the importance of a shared co-working space for the participants in a program. This factor affects synergies among the different teams, enabling peer-sharing of information and know-how. Similarly, the research refers to the ability of the SAO to offer access to funding for graduating ventures. Other influencing factors determined by this research refer to the involvement of venture capital investors and experienced entrepreneurs in the support services.

Chang (2013) also enhances the factor of support services by suggesting they need to support the venture in quickly transitioning from business idea to working prototype and market-ready product. This means, these services should be very practice oriented, not only theoretical. He also presents the importance of mentors for such ventures, as experienced individuals to more closely guide the team within the program.

Table 2. Relevant theoretical studies on factors influencing accelerator performance published between 2011 and 2013

\begin{tabular}{|c|c|}
\hline Author & Factors influencing SAO performance \\
\hline Ross \& Byrd, 2011 & $\begin{array}{l}\text { - Enabling innovative concepts and products to be marketable } \\
\text { - Selection of target industry of new ventures - focus on high-value } \\
\text { industries }\end{array}$ \\
\hline Tseng, 2011 & $\begin{array}{l}\text { - Human resource development approach: } \\
\quad \bigcirc \text { Selection of offered training workshops } \\
\circ \text { Type and quality of assistance offered to participants } \\
\text { - Surrounding sponsors } \\
\text { - Creation of opportunity } \\
\text { - Transforming property into productivity }\end{array}$ \\
\hline Barrehag et al., 2012 & $\begin{array}{l}\text { - Involvement of stakeholders (such as VCs or founders of prominent } \\
\text { - } \text { new ventures) } \\
\text { - Enared co-working space for creation of synergies } \\
\text { - Enabling participants access to the stakeholder ecosystem through } \\
\text { pitches } \\
\text { - Enabling new ventures access to funding }\end{array}$ \\
\hline Dalziel, 2012 & $\begin{array}{l}\text { - Location of program } \\
\text { - Participant Screening/ Selectivity } \\
\text { - Experience of the program's management team } \\
\text { - } \quad \text { Duration of program } \\
\text { - Industry focus }\end{array}$ \\
\hline
\end{tabular}




\begin{tabular}{|c|c|}
\hline Chang, 2013 & $\begin{array}{l}\text { - Enabling support to a venture for a quick transition from idea to } \\
\text { - } \text { developing a working prototype } \\
\text { - Access to mentors } \\
\text { - Access to business education } \\
\text { - Exposure to funding } \\
\text { - Access to alumni } \\
\text { - Participant Screening/ Selectivity }\end{array}$ \\
\hline $\begin{array}{l}\text { Guidelines - Metrics } \\
\text { \& Milestones, } 2013\end{array}$ & $\begin{aligned} \text { - Symbiotic association of ecosystem players } \\
\circ \text { Host organization } \\
\circ \text { Funding organizations } \\
\circ \text { Startup teams } \\
\circ \text { Community resources } \\
\circ \text { Policy organizations } \\
\end{aligned}$ \\
\hline Isabelle, 2013 & $\begin{array}{l}\text { - Compatibility between: } \\
\circ \text { Venture stage and the stage the program is focused on } \\
\circ \quad \text { Venture/ Entrepreneur needs and program mission/ } \\
\text { purpose/ sector focus } \\
\text { - Participant Screening/ Selectivity } \\
\text { - Graduation policies } \\
\text { - Nature and extend of services offered by the program (mentoring, } \\
\text { workshops, access to networks) }\end{array}$ \\
\hline Lall et al., 2013 & $\begin{array}{l}\text { - Organizational funding sources } \\
\text { - } \quad \text { Participant Screening/ Selectivity } \\
\text { - } \quad \text { Support services } \\
\text { - } \\
\text { - } \\
\text { Petwork opportunities } \\
\text { Post-Program support }\end{array}$ \\
\hline McHugh et al., 2013 & $\begin{array}{l}\text { - Region in which the program takes place } \\
\text { - Longevity of the program }\end{array}$ \\
\hline Tavoletti, 2013 & $\begin{array}{l}\text { - Selection of stakeholders } \\
\text { - } \text { Correct evaluation of population and economy level of the region } \\
\text { where the program activates } \\
\text { - } \text { Balance between stakeholder goals and program goals } \\
\text { - } \text { Participant Screening/ Selectivity } \\
\text { - Monitoring, counseling and allocation of resources } \\
\text { - } \quad \text { Effective use of technology for creating and sharing value for the } \\
\text { - } \quad \text { prientation on high-tech and knowledge intensive industries }\end{array}$ \\
\hline
\end{tabular}

PICBE | 268 Source: Authors' own contribution.

The white paper 'Guidelines - Metrics \& Milestones for Successful Incubator Development' elaborated by the Government of India (2013) talks about the importance of symbiotic association within the SAO network. This means there should be a close cooperation among all stakeholders: SAO, funding organizations, ventures, community resources and policy organizations. 
One of the most preeminent researches in this timeframe is the one of Isabelle (2013). In her study, she argues the importance of compatibility between the maturity stage of the venture and the stage the SAO focuses on, on the one hand, and, on the other hand, the venture or entrepreneur needs and the mission, purpose or sector focus of the program. Homogeneity among maturity stage of ventures in the same cohort allows for more relevant, effective and tailored support services within the program. Congruence of venture needs and program mission is an important factor directly influencing both venture and program performance, which means to use a strategic thinking pattern (Bratianu, 2007).

McHugh et al. (2013) considers that the location of the SAO has a great impact on its performance. His finding is also supported by Tavoletti (2013), who augments this factor by adding that a correct evaluation of the population and economy level of the region where the SAO is located has a direct impact. McHugh et al. (2013) implies also that the SAO longevity impacts its performance, due to high levels of credibility in the market and business environment.

The research of Tavoletti (2013) completes the review of this timeframe. Among other stated influence factors, his research shows that the selection of stakeholders impacts the quality and performance of the program, implying the need to curate the network around the SAO. He is also the first to mention the effective use of technology for creating and sharing value for participants.

\section{Synthesis of research published between 2014 and 2016}

The research published in the past two years further consolidates past research regarding influence factors (Table 3): support services, network opportunities, participant selection, program location, sector focus, synergies within the network and post-program support (Wise and Valliere, 2014; 'Global Best Practices Report on Incubation and Acceleration' by the Center of Digital Entrepreneurship + Economic Performance, 2015; Stokan et al., 2015; Knott and Haguewood, 2016; Rostarova and Rentkova, 2016).

Dempwolf et al. (2014) brings into discussion the necessity of a coherent value proposition of the SAO towards it participants as a performance influence factor, as well as access to the relevant customer market and a performing business model. He also speaks of rewards within the program, such as reduction of real and opportunity cost associated with the search of new investments for the stakeholders. Furthermore, he is the first to underline the value of the whole experience throughout the program as a performance factor of the SAO. Among other factors mentioned in this research, the research group mentions the ability of the SAO to offer alternatives (business incubators vs. business accelerators vs. other SAO programs) and differentiation (specific tailored programs function of industry, sector, mentoring, funding options) to the participants. 


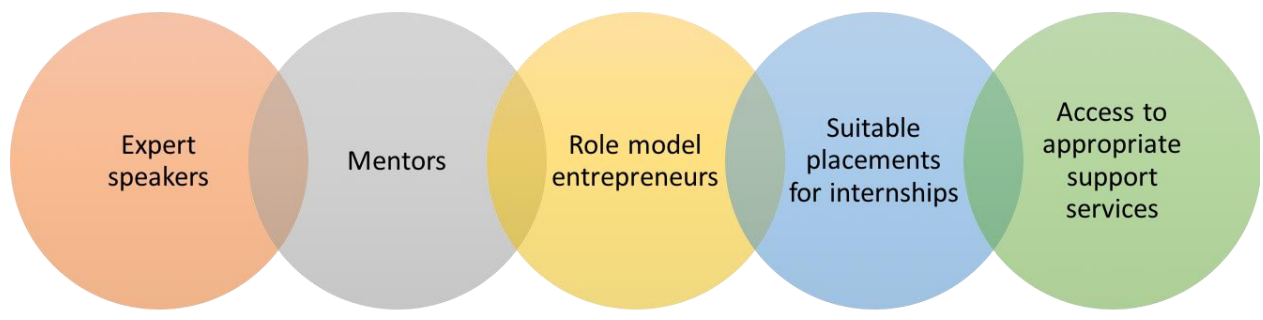

Figure 2. Resources of the entrepreneurship ecosystem of a SAO

Source: Authors' own contribution based on Valliere et al., 2014.

Valliere et al. (2014) states there is very little research on the performance (Dickson et al., 2008; Pittaway et al., 2009) of such programs, most of it being focused on design and implementation, themes such as participant attitudes, goals, competencies and behaviors (Duval-Couetil, 2013; Peterman \& Kennedy, 2003). However, he points out influence factors such as the ability to access the resources of the network in order to achieve new venture success. Another factor is the context in which the program is created (Figure 2) (Valliere et al., 2014).

Table 3. Relevant theoretical studies on factors influencing accelerator performance published between 2014 and 2016

\begin{tabular}{|c|c|}
\hline Author & Factors influencing SAO performance \\
\hline Dempwolf et al., 2014 & $\begin{array}{ll}\text { - } & \text { Coherent value proposition } \\
\text { - } & \text { Customer market } \\
\text { - } & \text { Activities } \\
\text { - } & \text { Rewards } \\
\text { - } & \text { Value experience } \\
\text { - } & \text { Alternatives and differentiation } \\
\text { - } & \text { Business model }\end{array}$ \\
\hline $\begin{array}{l}\text { Theodorakopoulos et al., } \\
2014\end{array}$ & 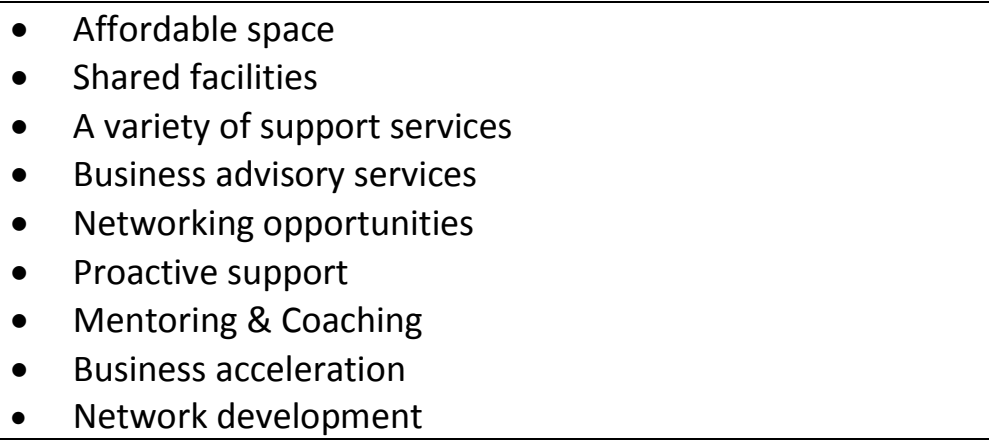 \\
\hline Velliers et al., 2014 & $\begin{array}{l}\text { - Stakeholder network management and its deployment } \\
\text { - } \quad \text { Entrepreneurship ecosystem } \\
\text { - } \text { Market demographics and competitive pressures of similar } \\
\text { programs } \\
\text { - Balance among competing stakeholder demands and } \\
\text { priorities } \\
\text { - Selection of target audience of the program } \\
\text { - } \quad \text { Implementation methodology }\end{array}$ \\
\hline Wise \& Valliere, 2014 & $\begin{array}{l}\text { - Experience of the program's management team } \\
\text { - Degree of connectedness of the management team } \\
\text { - Program location }\end{array}$ \\
\hline
\end{tabular}




\begin{tabular}{|c|c|}
\hline & $\begin{array}{l}\text { - } \\
\text { - } \\
\text { - } \\
\text { - Access to the knility to identify opportunities and synergies for the } \\
\text { participant ventures }\end{array}$ \\
\hline DEEPCenter, 2015 & $\begin{array}{l}\text { - } \text { Economic impact } \\
\text { - } \text { Focus on high-growth of participating ventures } \\
\text { - } \text { Direct involvement of venture capital funds } \\
\text { - Surrounding sponsors } \\
\text { - Focus on a specific sector/ industry } \\
\text { - Large network of capital resources (VCs, seed investors, } \\
\text { - } \text { angel investors, etc.) } \\
\text { - } \quad \text { Internationalization } \\
\text { - Orientation on building global startup networks }\end{array}$ \\
\hline $\begin{array}{l}\text { Global Best Practices Report } \\
\text { on Incubation and } \\
\text { Acceleration, } 2015\end{array}$ & $\begin{array}{l}\text { - } \quad \text { Sector focus } \\
\text { - } \quad \text { Structure of the program } \\
\text { - } \quad \text { Networking among peers } \\
\text { - } \quad \text { Program network depth (alumni, investors, etc.) }\end{array}$ \\
\hline Schenkel et al., 2015 & $\begin{array}{l}\text { - Quality of human resources involved in the program } \\
\text { (mentors, speakers, ets.) } \\
\text { - Quality of knowledge shared within the program } \\
\text { - Access to advice networks }\end{array}$ \\
\hline Stokan et al., 2015 & $\begin{array}{l}\text { - } \text { Participant Screening/ Selectivity } \\
\text { - Sector focus } \\
\text { - } \quad \text { Location of program } \\
\text { - } \text { Networking opportunities } \\
\text { - Support services }\end{array}$ \\
\hline Bliemel et al., 2016 & $\begin{array}{l}\text { - } \text { Funding Opportunities } \\
\text { - Brand/Alumni Connection } \\
\text { - } \text { Business/Product Development Support } \\
\text { - } \text { Mentorship } \\
\text { - Entrepreneurial Culture } \\
\text { - Synergistic Environment } \\
\end{array}$ \\
\hline Rostarova \& Rentkova, 2016 & $\begin{array}{l}\text { - } \text { Participant Screening/ Selectivity } \\
\text { - Enabling synergies among participant ventures } \\
\text { - Support in negotiations with potential investors } \\
\text { - Guidance in communication and/ or presentation to } \\
\text { - } \text { potential investors } \\
\text { - Access to financial resources during the program }\end{array}$ \\
\hline $\begin{array}{l}\text { Mejia \& Gopal, working } \\
\text { paper }\end{array}$ & $\begin{array}{l}\text { - Mentorship } \\
\text { - Investor ties }\end{array}$ \\
\hline
\end{tabular}

PICBE | 271 


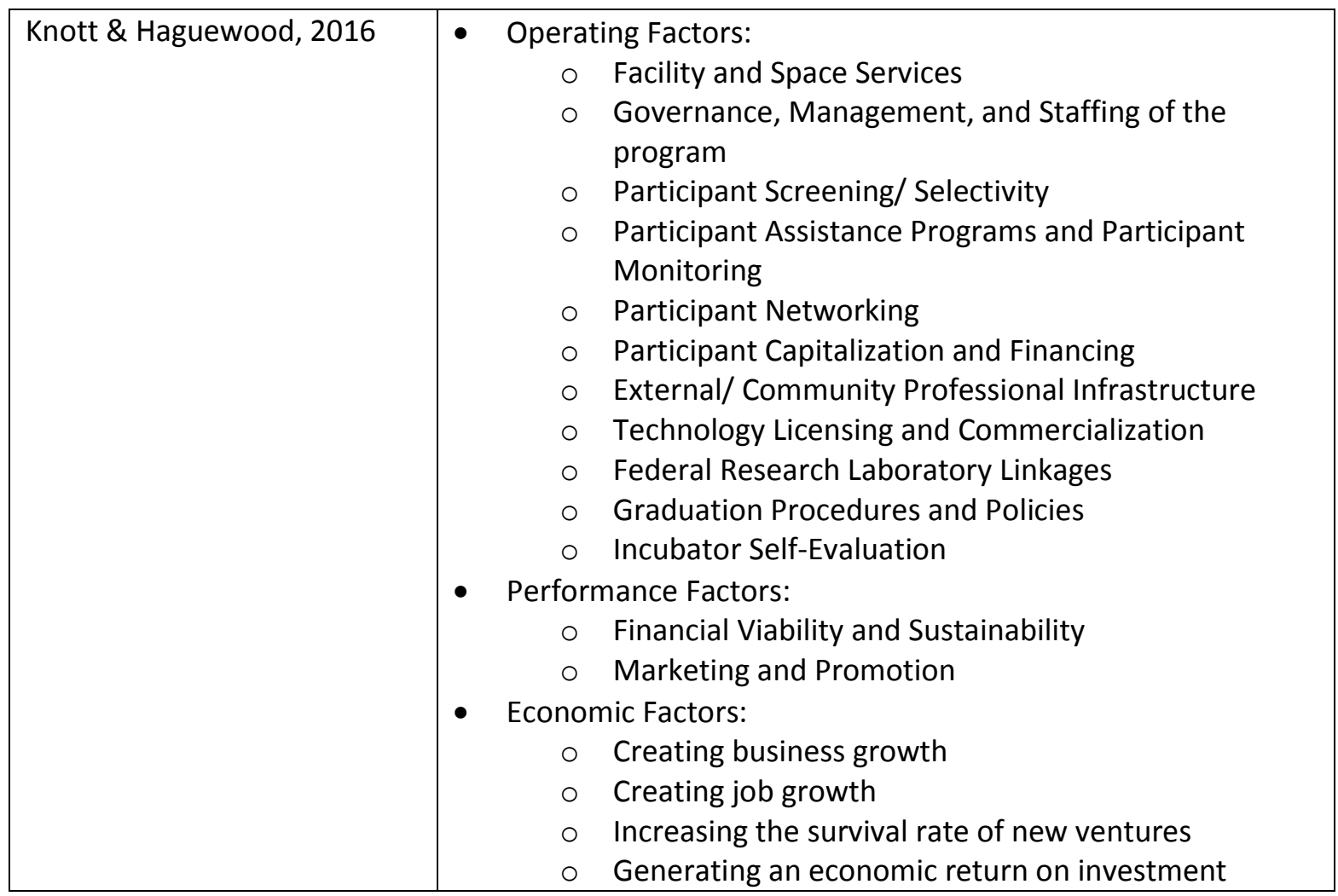

PICBE | 272

The DEEPCenter report, 'Global Best Practices in Business Acceleration: Charting the Evolution and Performance of the World's Leading Accelerators' (2015) brings a more highlevel view on the matter of influence factors. Along with economic impact of the SAO, its surrounding network of sponsors and investors and the focus on a specific sector, the study brings forward the importance of internationalization and the orientation towards building a global network around the SAO.

The research of Schenkel et al. (2015) brings for the first time in the foreground the importance not only to offer mentorship, support services, etc. and knowledge transfer within the SAO programs, but also to curate these properly and select only high-quality human resources, training programs and network stakeholder. He also enhances the influence factor mentorship, underlining the fact that enabling participants access so-called advice networks, not only singular individuals will increase the performance of both the SAO and the ventures.

Starting with 2016 focus is placed more and more on factors such as mentorship quality and networks, nurturing an entrepreneurial culture within the SAO and building a synergistic environment (Bliemel et al., 2016). The synergy factor is also supported by Rostarova \& Rentkova (2016), which imply it should also comprise cooperation among fellow ventures within the same cohort or with alumni. Their research also adds for the first time the factor referring to the support SAO offer ventures in preparing investor pitches and negotiations. The last paper included in this literature review is still a working paper of Meija and Gopal, which emphasizes the importance of mentorship quality and investor ties for the success of a SAO. 


\section{Conclusion}

After reviewing the relevant articles in the past 6 years about performance of SAOs the authors identified which factors are considered important within the research community and observed an evolution trend within the evolution of these factors affecting the performance of programs within SAOs. In Figure 3 are the main influence factors studies took into review in each synthesized research time-frame.

It can be noticed that the main concerns are focused on co-production, participant selection, program duration, network opportunities and resource munificent. As such programs evolved together with the dynamic development of the business environment, performing SAOs started to focus on the quality of the human resources deployed in their programs, on a specific target industries for their participant ventures, on the location of the program and on the creation of opportunities for these in an ever more symbiotic entrepreneurial ecosystem. Also, post-program support became more influential as a success factor. In the past two years, the coherent value proposition and business model of the SAO were stressed as influential, together with strong mentorship networks and investor ties, the fostering of entrepreneurial culture and focus on high-growth ventures. The experience within the SAO programs also gained the attention of the research community.

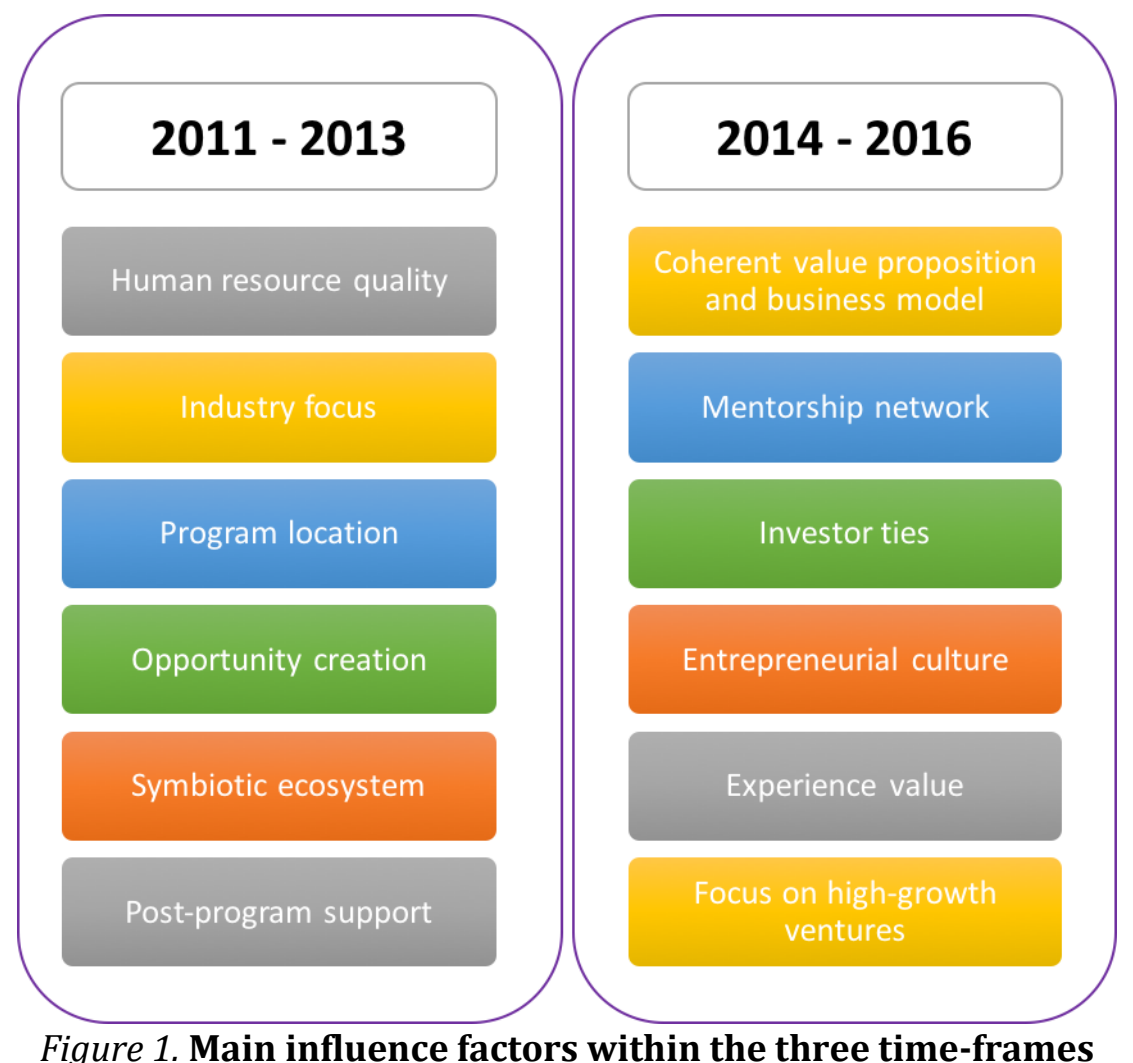

Figure 1. Main influence factors within the three time-frames

Source: Authors' own contribution.

This leads to the need of further quantitative and qualitative empirical research together with SAOs in identifying qualitative aspects of influential factor deployment. Looking at the factors influencing SAO performance, it can be noticed that they are closely linked to the performance evolution of the ventures these organizations are fostering and supporting. 


\section{References}

Bliemel, M., Flores, R., De Klerk, S., Miles, M., Costas, B. and Monteiro, P., (2016). The Role and Performance of Accelerators in Australian Startup Ecosystem. Final Report for the Department of Industry, Innovation \& Science, UNSW Australia.

Bratianu, C. (2007). Thinking patterns and knowledge dynamics. In D. Remenyi (Ed.). Procedings of the $8^{\text {th }}$ European Conference on Knowledge Management (pp. 152-156), Consorci Escola Industrial, Barcelona, Spain, 6-7 September 2007.

Chang, C., (2013). Portfolio Company Selection Criteria: Accelerators vs Venture Capitalists. CMC Senior Theses, Paper 566, at http://scholarship.claremont.edu/cmc_theses/566 (accessed on February 10th 2017).

Dalziel, M. (2012). A Study of Business Incubators and Business Accelerators in Canada. The Evidence Network available at http://www.theevidencenetwork.com/media/3639/ten_2012_bis_and_bas.pdf (accessed on February 10th 2017).

Dempwolf, C. S., Auer, J. and D'Ippolito, M., (2014). Innovation Accelerators: Defining Characteristics among Startup Assistance Organizations. Small Business Administration, Office of Advocacy, Optimal Solutions Group, LLC College Park, MD 20740.

Dickson, P., Solomon, G. and Weaver, K.M., (2008). Entrepreneurial Selection and Success: Does Education Matter? Journal of Small Business and Enterprise Development, 15 (2), p. 239-258.

Duval-Couetil, N., (2013). Assessing the Impact of Entrepreneurship Education Programs: Challenges and Approaches. Journal of Small Business Management, 51 (3), 394 409.

Global Best Practices in Business Acceleration: Charting the Evolution and Performance of the World's Leading Accelerators". Centre for Digital Entrepreneurship + Economic Performance, 2015 Retrieved from http://deepcentre.com/wordpress/wpcontent/uploads/2015/10/DEEP-Centre-BABI-4-Global-Best-Practices-in-

Acceleration-September-20151.pdf (accessed February 10th 2017).

Guidelines - Metrics \& Milestones for Successful Incubator Development - A White Paper. Department of Science \& Technology, Government of India, National Entrepreneurship Network, 2013 Retrieved from http://c.ymcdn.com/sites/www.andeglobal.org/resource/dynamic/blogs/2015060 9_144829_13974.pdf (accessed on February 10th 2017).

Isabelle, D. A., (2013). Key Factors Affecting a Technology Entrepreneur's Choice of Incubator or Accelerator. Technology Innovation Management Review, 16 - 22.

Knott, F. and Haguewood, J., (2016), "SoVermont Business Accelerator Feasability Study", Vital Economy Alliance Retrieved from http://brattleborodevelopment.com/wpcontent/uploads/2016/10/SEVEDS-042716-Accelerator-Feasibility-Final-2.pdf (accessed on February 10th 2017).

Lall, S., Bowles, L. and Baird, R., (2013). Bridging the 'Pioneer Gap': The Role of Accelerators in Launching High-Impact Enterprises. Innovations: Technology, Governance, Globalization, quarterly published by MIT, 8 (3/4), 105 - 137.

Mejia, J. and Gopal, A.. Now and Later? Mentorship, Investor Ties and New Venture Performance in Entrepreneurial Seed Accelerators. Working Paper, Target: MIS Quarterly. 
McHugh, P., Whipple, C. and Yang, X., (2013). Failing to Succeed: A Network Theoretic Comparison of Global Accelerators. Proceedings of the European Conference on Innovation and Entrepreneurship, Brussels, Belgium, 425 - 433.

Miller, P. and Bound, K., (2011). The Startup Factories: The Rise of Accelerator Programs to Support New Technology Ventures. NESTA, London.

Peterman, N.E. and Kennedy, J., (2003). Enterprise Education: Influencing Students' PICBE| 275 Perceptions on Entrepreneurship. Entrepreneurship Theory \& Practice, 28 (2), 129 144.

Pittaway, L., Hannon, P., Gibb, A. and Thompson, J., (2009). Assessment Practice in Enterprise Education. International Journal of Entrepreneurial Behaviour \& Research, 15(1), $71-93$.

Ross, L.W. and Byrd, K.A., (2011). Business Plan Competitions: Start-up "Idols" and Their Twenty-First Century Launch Pads. Journal of Higher Education Theory and Practice, 11, 53 - 64.

Rostarova, M. and Rentkova, K., (2016). Investment Criteria of the Successful Start-up Accelerators. 18th International Scientific Conference on Economic and Social Development - "Building Resilient Society" - Zagreb, Croatia, 9-10 December Retrieved from http://search.proquest.com/openview/cfc76f4525d050a689632e34478c6e13/1.pd f?pq-origsite $=$ gscholar\&cbl=2033472 (accessed on February 10th 2017).

Schenkel, M. T., D'Souza, R. R., Cornwall, J. R. and Metthews, C. H., (2015). Early Influences and Entrepreneurial Intent: Examining the Role of Education. Experience and Advice Networks, Journal of Small Business Strategy, 25 (2), 1 - 20.

Stokan, E., Thompson, L., and Mahu, R. J., (2015). Testing the Differential Effect of Business Incubators on Firm Growth. Economic Development Quarterly, 29 (4), 317 - 327.

Tavoletti, E., (2013). Business Incubators: Effective Infrastructures or Waste of Public Money? Looking for a Theoretical Framework, Guidelines and Criteria. Journal of the Knowledge Economy, Springer, 4, p. 423 - 443.

Theodorakopoulos, N., Kakabadse, N. K. and McGowan, C., (2014). What Matters in Business incubation? A literature Review and a Suggestion for Situated Theorising. Journal of Small Business and Enterprise Development, 21 (4), 602 - 622.

Tseng, C., (2011). Connecting Business Incubator Development with Human Resource Development. Journal of Multidisciplinary Research, 3(2), $29-42$.

Yusuf, J.-E., (2010). Meeting entrepreneurs' support needs: are assistance programs effective?. Journal of Small Business and Enterprise Development, 17 (2), 294 - 307.

Valliere, D., Gedeon, S.A. and Wise, S., (2014). A Comprehensive Framework for Entrepreneurship Education. Journal of Business \& Entrepreneurship, Special Edition, $89-120$.

Wise, S. and Valliere, D., (2014). The Impact on Management Experience on the Performance of Start-ups within Accelerators. The Journal of Private Equity, 18 (1), 9 $-19$. 